\title{
Comprehensive Analysis of the Testing Techniques Used in Blood Bank Laboratories in Korea for the Past Six Years
}

Young Ae Lim

Department of Laboratory Medicine, Ajou University School of Medicine, Suwon, Korea

Corresponding author: Young Ae Lim Department of Laboratory Medicine, Ajou University School of Medicine, 164 Worldcup-ro, Yeongtong-gu, Suwon 443-721, Korea

Tel: +82-31-219-5786

Fax: +82-31-219-5778

E-mail: limyoung@ajou.ac.kr
Background: The results of a particular test can be affected by the techniques used for testing. However, limited data is available on the testing techniques used in blood bank laboratories in Korea. The aim of this study was to evaluate the various testing techniques used in blood bank laboratories using the data obtained during the past six years from the Korean external quality assessment (KEQA) of blood bank laboratories.

Methods: Data was collected from all KEQA respondents via the KEQA website on the testing techniques used in blood bank laboratories from 2008 to 2013. The survey included questions on $\mathrm{ABO}$ grouping, $\mathrm{D}$ typing, crossmatching tests, direct antiglobulin tests (DAT), antibody (Ab) screening, and $\mathrm{Ab}$ identification (ID) tests.

Results: Based on the data obtained from 2008 to 2013 (ABO grouping data obtained from 2011 to 2013), the most frequently used techniques are as follows: slide agglutination (60.7\% and $60.8 \%$ ) for $\mathrm{ABO}$ cell typing; tube agglutination (78.2\% and $81.2 \%$ ) for $\mathrm{ABO}$ serum typing; slide agglutination (50\% and 54.6\%) for D typing; tube agglutination (91.9\% and $83.8 \%)$ for crossmatching tests; tube agglutination $(63.6 \%$ and $52.8 \%)$ for DAT; column agglutination technique (CAT; $74.5 \%$ and $89.4 \%$ ) for Ab screen; and CAT (83.9\% and $94.2 \%$ ) for Ab ID.

Conclusions: The findings reveal a steady increase in the use of CAT from 2008 to 2013 for crossmatching tests, DAT, Ab screen, and Ab ID and a decreasing use of the tube agglutination technique for the past six years. Since the slide agglutination technique accounted for a significant percentage of the tests conducted, further education is warranted on the improvement in the techniques used for $\mathrm{ABO}$ and $\mathrm{D}$ typing.

(J Lab Med Qual Assur 2014;36:23-29)

Key Words : Agglutination test, Blood banks, Clinical laboratory technique

\section{서론}

혈액은행에서 수혈 전에 시행하는 $\mathrm{ABO}$ 및 $\mathrm{D}$ 혈액형검사, 비예기항체 선별 및 동정검사, 교차시험은 환자의 생명과도 직 결될 수 있으므로 정확성이 요구되는 중요한 검사이다. 대부분 의 국내 검사실에서 이러한 검사들은 적혈구와 혈장 혹은 혈청 을 이용한 면역혈구 응집법검사를 사용하는데 자동화장비를 이용하기보다는 수기법으로 시행하고 있는 실정이다[1,2]. 면 역혈구 응집법검사기법으로는 시험관이나 슬라이드를 이용하 는 전통적인 방법 이외에도 최근에는 자동화가 가능한 미세원 주응집법(column agglutination technique), 고형상적혈구부 착법(solid phase red cell adherence assay), 그리고 적혈구 자기화법(erythrocyte-magnetized technique)을 이용하는 새 로운 기법들이 소개되고 있다[3,4].

대한임상검사정도관리협회 혈액은행 분과에서는 $\mathrm{ABO}$ 및 $\mathrm{D}$ 혈액형검사, 직접항글로불린검사, 교차시험, 항체선별 및 항체동정검사에 대한 외부신빙도조사를 실시해오면서 각 검 사방법들을 참여기관으로부터 입력하도록 하였으나 이에 대 한 국내 정식 논문은 없는 실정이다 $[1,2,5,6]$. 또한 저자들은 2011년부터 처음으로 ABO 혈액형검사법에 대해서는 혈구형 
검사와 혈청형검사방법에 대하여 참여기관들이 각기 입력하 는 업무도 시작하였다. 이에 2008년부터 2013년까지의 혈액 은행검사에 사용된 기법들에 대한 자료를 수집할 수 있었기에 국내에서는 처음으로 혈액은행검사에 대한 검사실 현황의 기 초자료를 제시하고 외국의 자료와 비교하여 국내 검사실의 나 아갈 바를 제시하고자 하였다.

\section{대상 및 방법}

조사대상기관은 2008년부터 2013년도까지 혈액은행 외부 신빙도조사에 참여하여 답변과 방법에 표기를 하였던 기관들 을 대상으로 하였다. 연도별 평균 응답기관 수는 Table 1에 기 술되어 있다.

조사방법은 $\mathrm{ABO}$ 혈액형검사, $\mathrm{D}$ 혈액형검사, 교차시험검사, 직접항글로불린검사, 비예기항체 선별검사 및 동정검사마다
각 연도별 평균 값을 사용하였다. 즉, 2008년부터 2010년까지 는 3회차 결과, 2011 부터 2013년까지는 2회차 결과의 평균값 을 각 연도별 평균 결과로 간주하였다.

$\mathrm{ABO}$ 혈액형검사의 경우 혈구형 검사와 혈청형 검사법 의 분리가 가능한 2011부터 2013년까지는 각각 산정하였고, 2008년부터 2010년까지는 표기한 검사법으로 간주하였다. 입 력방법은 괄호 안의 검사법을 각 검사법 코드번호로 선택하 도록 하였는데, 1) tube (시험관법), 2) 미세원주응집법, 3) Microwell (liquid microwell plate, 마이크로웰 플레이트), 4) Slide(플레이트나 슬라이드), 5) Other (1-4 이외의 기타 방법)의 5 가지 중 한 가지를 선택하도록 하였다. 입력된 자료 는 대한임상검사정도관리협회 홈페이지의 외부정도관리(신 빙도조사) 혈액은행분과의 각 회차별 결과조회를 검색하여 Microsoft Excel 2010 (Microsoft, Redmond, WA, USA)로 저장하여 이용하였다.

Table 1. Average number of respondents during the given years and the testing techniques used in Korean blood bank laboratories

\begin{tabular}{|c|c|c|c|c|c|c|}
\hline \multirow{2}{*}{ Variable } & \multicolumn{6}{|c|}{ Year } \\
\hline & 2008 & 2009 & 2010 & 2011 & 2012 & 2013 \\
\hline ABO typing & 457 & 479 & 495 & 504 & 511 & 531 \\
\hline D typing & 456 & 479 & 490 & 497 & 504 & 526 \\
\hline Crossmatching test & 402 & 423 & 441 & 445 & 447 & 465 \\
\hline Direct antiglobulin test & 318 & 325 & 342 & 360 & 364 & 370 \\
\hline $\mathrm{Ab}$ screening test & 235 & 244 & 252 & 259 & 265 & 274 \\
\hline Ab identification test & 115 & 116 & 122 & 126 & 131 & 138 \\
\hline
\end{tabular}

Abbreviation: $\mathrm{Ab}$, antibody.

Table 2. Average percentage of respondents on the cell and serum typing techniques used for ABO grouping

\begin{tabular}{|c|c|c|c|c|c|}
\hline \multicolumn{2}{|c|}{ Techniques } & \multicolumn{4}{|c|}{ Year } \\
\hline Cell typing & Serum typing & 2011 & 2012 & 2013 & Average \\
\hline Slide & Tube & 40.3 & 42.6 & 43.4 & 42.1 \\
\hline Tube & Tube & 37.7 & 37.3 & 37.7 & 37.5 \\
\hline Slide & Slide & 15.2 & 14.1 & 12.4 & 13.9 \\
\hline Slide & Not done & 5.2 & 4.6 & 5.0 & 4.9 \\
\hline Tube & Not done & 0.6 & 0.2 & 0.3 & 0.4 \\
\hline CAT & CAT & 0.3 & 0.4 & 0.4 & 0.4 \\
\hline CAT & UD & 0.2 & 0.3 & 0.1 & 0.2 \\
\hline Microwell & Tube & 0.2 & 0.3 & 0.1 & 0.2 \\
\hline Microwell & Microwell & 0.3 & 0.3 & 0.5 & 0.4 \\
\hline Microwell & UD & 0.0 & 0.0 & 0.1 & 0.0 \\
\hline
\end{tabular}

Abbreviations: CAT, column agglutination technique; Microwell, liquid microwell plate; UD, suspected unreliable data. 


\section{결과}

\section{1. $\mathrm{ABO}$ 및 $\mathrm{D}$ 혈액형검사}

2008년부터 2010년까지의 결과는 슬라이드법과 시험관법 이 거의 유사한 비율을 보인 반면, 혈구형 검사와 혈청형 검사 법의 분리가 가능하였던 2011부터 2013년에는 혈구형 검사는 슬라이드법이 가장 많아 60.8-61.3\%를 차지하였으며, 혈청 형 검사는 시험관법이 가장 많아 $78.2-81.2 \%$ 이상을 차지하 였다(Table 2).

2011부터 2013년까지의 기관별 $\mathrm{ABO}$ 혈액형검사기법을 살 펴보면 혈구형 슬라이드법과 혈청형 시험관법을 사용하는 기 관이 전체 기관의 $42.1 \%$ 로 가장 많았으며, 다음으로는 혈구

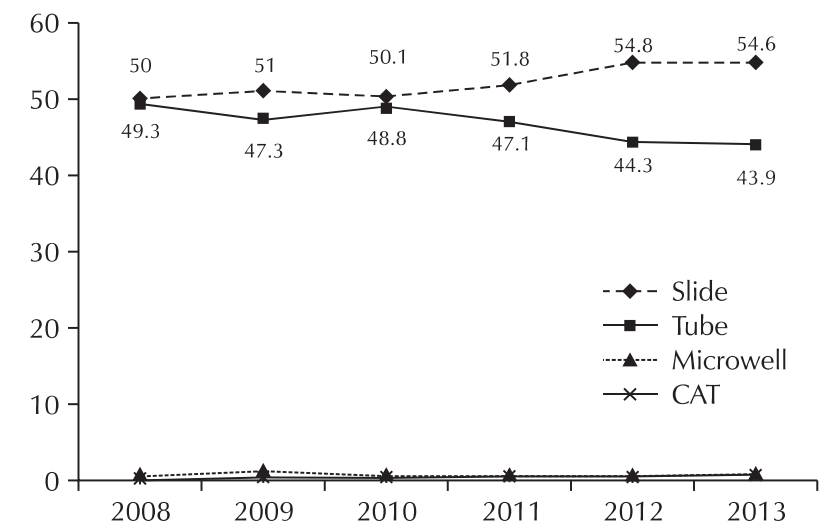

Fig. 1. Relationship between the years and average percentage of respondents for techniques used for $\mathrm{D}$ typing. The average percentage of respondents for both the column agglutination technique (CAT) and the liquid microwell plate method is less than $1 \%$.

A

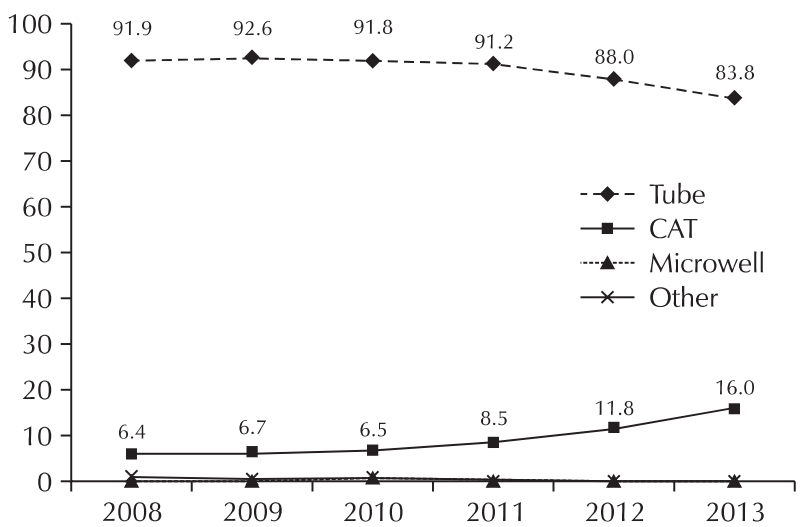

형과 혈청형 모두 시험관법을 사용하는 기관이 전체 기관의 $37.5 \%$ 를 차지하였다(Table 2). 그러나 혈구형 검사만 시행하 는 기관도 $5.3 \%$ 를 차지하였다. 혈구형 검사 시 자가제조가 아 닌 상품화 적혈구는 사용하는 비율은 2011년 35.5\%, 2012년 $38.2 \%, 2013$ 년 34.5\%였다.

$\mathrm{D}$ 혈액형검사는 슬라이드법을 시행하는 기관이 시험관법을 시행하는 기관보다 더 많아 2013년 54.6\%를 차지하였으며, 연도가 증가할수록 슬라이드법이 점점 더 증가하는 양상을 보 였다(Fig. 1). 그러나 혈액형검사에서 슬라이드법이나 시험관 법 이외의 미세원주응집법을 사용하는 기관은 모두 $1 \%$ 미만 을 차지하였다.

\section{2. 교차시험검사와 직접항글로불린검사}

교차시험은 연도가 증가할수록 시험관법을 사용하는 기관은 $91.9 \%$ 에서 $83.8 \%$ 로 감소하는 반면 미세원주응집법을 사용하 는 기관은 $6.4 \%$ 에서 $16.0 \%$ 로 6 년 사이에 2 배가 증가하였다. 직접항글로불린검사도 연도가 증가할수록 시험관법을 사용하 는 기관은 $63.6 \%$ 에서 $52.8 \%$ 로 감소하는 반면 미세원주응집 법을 사용하는 기관은 $32.4 \%$ 에서 $46.7 \%$ 로 증가하였다(Fig. 2). 그리고 기타 검사법을 사용하는 기관은 모두 $1 \%$ 미만이었 다.

\section{3. 항체선별검사와 항체동정검사}

항체선별검사와 항체동정검사 모두 해가 갈수록 미세원주 응집법을 사용하는 기관들이 점점 증가하였으며, 2013년에는 각각 참여기관의 $89.4 \%$ 와 $94.2 \%$ 에서 미세원주응집법을 사 용하였다. 반면 시험관법을 사용하는 기관은 모두 $10 \%$ 이하 로 감소하였으며, 마이크로웰 플레이트법을 사용하는 기관도

B

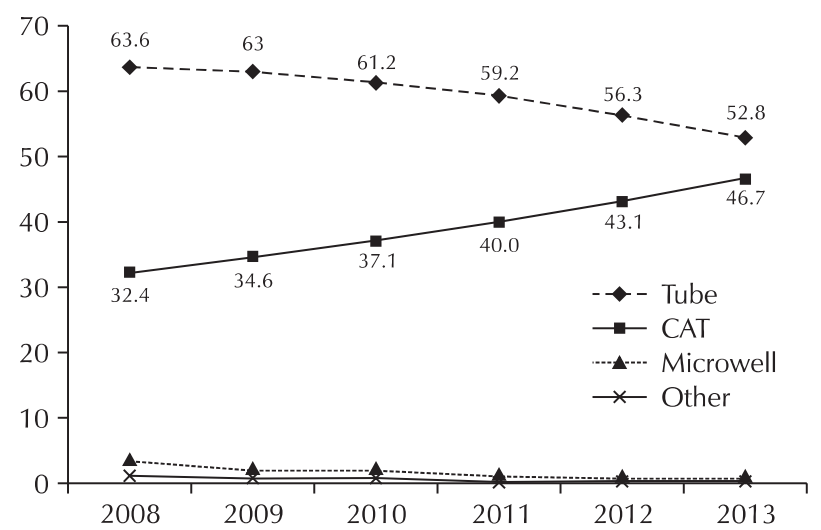

Fig. 2. Relationship between the years and average percentage of techniques used for (A) crossmatching and (B) direct antiglobulin testing. Abbreviation: CAT, column agglutination technique. 
A

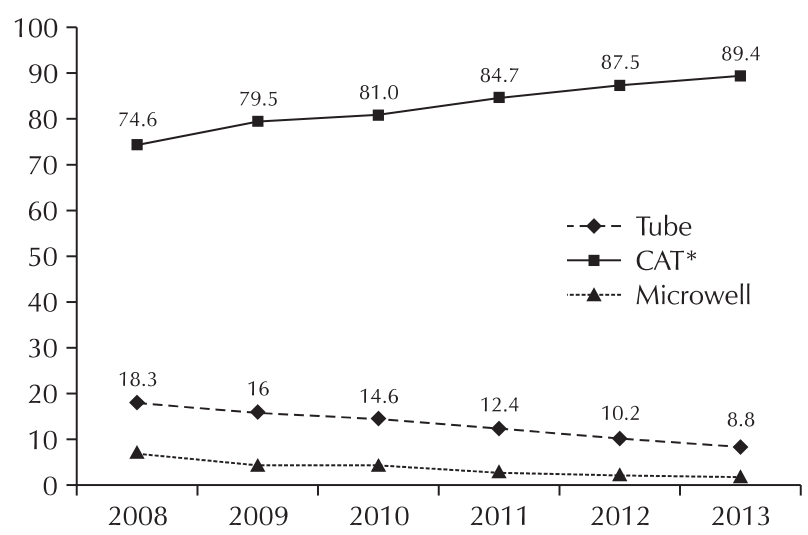

B

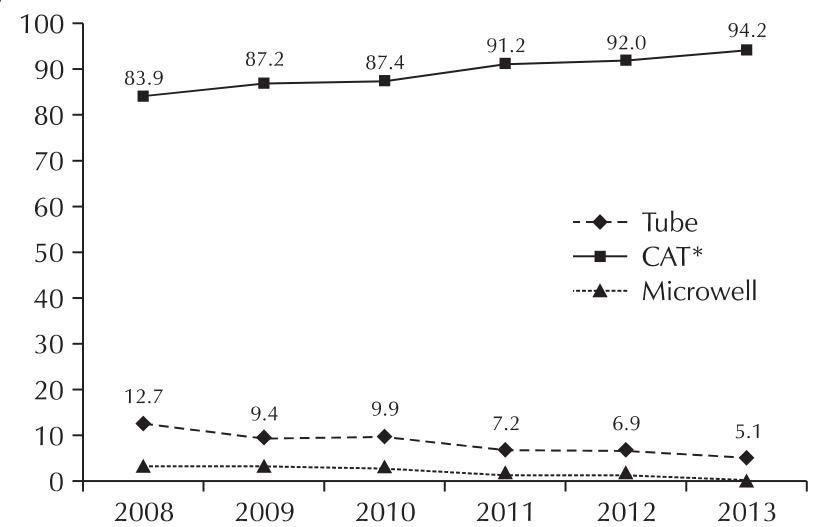

Fig. 3. Relationship between the years and average percentage of techniques used for (A) antibody screening and (B) antibody identification. Abbreviation: CAT, column agglutination technique.

2008년과 2013년에 각각 항체선별검사가 참여기관의 $7.1 \%$ 와 $1.8 \%$, 항체동정검사는 $3.4 \%$ 와 $0.7 \%$ 로 역시 점점 감소하였다 (Fig. 3).

\section{고찰}

2008년부터 2010년까지의 결과는 슬라이드법과 시험관법 이 거의 유사한 비율을 보였는데 2011부터 2013년 혈구형과 혈청형 검사법의 비율을 감안할 경우 참여기관들이 2008년부 터 2010년까지는 ABO 혈액형검사법을 정확히 입력하기에는 한계가 있었음을 알 수 있었다.

$\mathrm{ABO}$ 혈구형 검사와 $\mathrm{D}$ 혈액형검사에서 시험관법보다 슬라 이드법이 연도가 갈수록 증가하고 있는 이유는 신규기관들이 슬라이드법을 사용하기 때문인 것으로 여겨졌다. 즉 2011-1차 에 비하여 2013-2차 조사 시의 신규기관들의 66.7\% (26/39) 와 $61.5 \%$ (24/39)가 $\mathrm{ABO}$ 혈구형 검사와 D 혈액형검사를 슬 라이드법으로 사용하였다(자료는 제시하지 않음). 또한 혈청 형 검사를 슬라이드법으로 시행하고 있는 기관도 2013년도에 는 $12.4 \%$ 나 되는데, 이는 가급적 시험관법으로 전환할 필요 가 있겠다. 왜냐하면 슬라이드법은 단클론항체 시약에 비하 여 항체가가 낮은 혈청 $\mathrm{ABO}$ 항체를 검출하기에는 적당하지 않은 방법이며 검사 시 감염에 노출될 위험도 시험관법에 비 하여 높기 때문이다[7]. 2013년 미국의 병리협회 외부신빙도 조사(College of American Pathologists [CAP], 2013 J-A. Final critique of Transfusion Medicine [comprehensive] 보 고서에서 자료 발췌함)와 2008년 영국의 외부신빙도조사(UK National External Quality Assessment Scheme [NEQAS]) [8]와 비교한 Table 3에서 나타나듯이, 미국과 영국이 $\mathrm{ABO}$ 와
$\mathrm{D}$ 혈액형검사 시 슬라이드법을 사용하는 기관은 없는데 반하 여 국내의 과반수 이상의 기관은 슬라이드법을 사용하고 있는 것으로 나타났다. $\mathrm{ABO}$ 혈액형검사법으로 미국의 시험관법 과 미세원주응집법의 비율이 약 $73 \%$ 와 $26 \%$ 인데 비하여 영국 은 약 $8 \%$ 와 $77 \%$ 의 상반된 비율을 보여주었다. 영국은 $\mathrm{ABO}$ 혈액형검사법의 경우 시험관법, 슬라이드법과 미세원주응집 법의 사용 비율은 1982 년 $86 \%, 29 \%, 0 \%$ 였다가 1996년 각 각 $50 \%, 8 \%, 7 \%, 2002$ 년 24\%, $1 \%$ 미만과 33\%였다가 2005 년 미세원주응집의 비율이 $64 \%$ 로 급격히 증가한 것으로 보고 되었다[8]. 미국의 병리협회 외부신빙도조사 보고에 따르면 $\mathrm{ABO}$ 혈액형검사법의 경우 시험관법과 미세원주응집법의 사 용 비율이 2001년 97.6\%와 1.2\%, 2004년 91.1\%와 8.2\%로 변화되었다[9]. 조사대상 검사법에서 슬라이드법을 통계에서 제외하고 있는 것으로 보아 미국병리협회 외부신빙도조사에 서는 슬라이드법을 적절한 $\mathrm{ABO}$ 의 검사법으로 인정하지 않거 나 혹은 참여기관 중에는 슬라이드법을 사용하는 기관이 없는 것으로 해석할 수 있겠다. 그러나 $\mathrm{ABO}$ 혈액형검사 시 슬라이 드법 사용에 대하여 국내와 미국 및 영국과의 상당한 차이에 대한 정확한 사유는 분석할 수 없었으나, 분명한 것은 국내에 서는 $\mathrm{ABO}$ 혈액형검사 시 현재 미국과 영국에서는 사용하고 있지 않은 슬라이드법의 국내 사용기관이 과반수를 넘으며 이 의 가장 큰 이유는 국내의 열악한 혈액형검사 수가와 국내 검 사실에서 보편적으로 사용되고 있는 슬라이드법을 선택해도 부담이 없다는 것이 주 원인으로 생각되었다.

물론 국내에서 자동화장비를 사용하는 기관이더라도 외부신 빙도조사 시 숙련도물질의 특성상 직접 장비에 장착하지 못하 는 경우 대신 기존 수기법으로 시행하여 입력하는 경우가 많이 있으므로, 실제 사용보다 자동화장비 사용 비율이 더 낮게 평 
Journal of LABORATORY MEDICINE and QUALITY ASSURANCE

Young Ae Lim • Analysis of the Techniques in Blood Bank

Table 3. Relationship between external proficiency program and average percentage of techniques used for pretransfusion testing

\begin{tabular}{|c|c|c|c|c|c|c|c|}
\hline Tests & External proficiency program & Tube & Microwell & CAT & SPRCA & Slide & Other \\
\hline \multirow[t]{3}{*}{$\mathrm{ABO}$} & CAP $(2013, n=3,433)$ & 73.7 & 0.1 & 26.2 & 0.0 & 0.0 & 0.0 \\
\hline & KEQAS $(2013, \mathrm{n}=531)^{\star}$ & 38.1 & 0.7 & 0.5 & 0.0 & 60.7 & 0.0 \\
\hline & UK NEQAS $(2008, \mathrm{n}=388)$ & 8.0 & 14.0 & 77.0 & 1 & 0.0 & 0.0 \\
\hline \multirow[t]{2}{*}{$\mathrm{D}$} & CAP $(2013, n=3,422)$ & 73.5 & 0.2 & 26.3 & 0.0 & 0.0 & 0.0 \\
\hline & KEQAS $(2013, \mathrm{n}=526)$ & 43.9 & 0.8 & 0.8 & 0.0 & 54.5 & 0.0 \\
\hline \multirow[t]{3}{*}{$\mathrm{Ab}$ screen } & CAP $(2013, n=3,420)$ & 31.0 & & 65.6 & 3.4 & 0.0 & 0.0 \\
\hline & KEQAS $(2013, \mathrm{n}=274)$ & 8.8 & 1.8 & 89.4 & 0.0 & 0.0 & 0.0 \\
\hline & UK NEQAS $(2008, \mathrm{n}=389)^{\dagger}$ & $<1$ & 0.0 & 90.0 & 9.0 & 0.0 & $<1$ \\
\hline \multirow[t]{2}{*}{ Ab identification } & CAP $(2013, n=1,337)$ & 33.4 & & 61.3 & 5.3 & 0.0 & 0.0 \\
\hline & KEQAS $(2013, \mathrm{n}=138)$ & 5.1 & 0.7 & 94.2 & 0.0 & 0.0 & 0.0 \\
\hline \multirow[t]{3}{*}{ Crossmatching } & CAP $(2013, \mathrm{n}=3,044)$ & 49.7 & & 50.0 & 0.3 & 0.0 & 0.0 \\
\hline & KEQAS $(2013, \mathrm{n}=465)$ & 83.8 & 0.2 & 16.0 & 0.0 & 0.0 & 0.0 \\
\hline & UK NEQAS $(2008, \mathrm{n}=381)^{\dagger}$ & 3.0 & 0.0 & 96.0 & 0.0 & 0.0 & $<1$ \\
\hline
\end{tabular}

CAP data from '2013 J-A. Final critique of Transfusion Medicine (comprehensive)' and UK NEQAS data from reference [8].

Abbreviations: Microwell, liquid microwell plate; CAT, column agglutination technique; SPRCA, solid phase red cell adherence; CAP, College of American pathologists; KEQAS, Korea Association of Quality Assurance for clinical laboratories; UK NEQAS, United Kingdom National External Quality Assessment Scheme; Ab, antibody.

${ }^{\star}$ Only for cell typing. ${ }^{\dagger}$ Only for indirect antiglobulin tests.

가될 가능성도 있다. 그러나 이점을 고려한다 하더라도 국내의 자동화장비 사용 비율은 낮으므로, 혈액형검사 시 슬라이드법 대신 시험관법과 기타 자동화가 가능한 방법이 국내에서도 널 리 이용될 수 있도록 지속적인 교육이 필요하고, 이에 대한 현 실적인 의료보험의 수가가 필요할 것으로 여겨졌다.

영국에서는 신규 환자인 경우 $99 \%$ 이상의 기관들이 혈구형 과 혈청형 검사를 모두 시행하며, 이미 혈액형을 알고 있는 기 존 환자들의 경우 $25 \%$ 기관에서 혈청형 검사를 생략한다고 하였다[8]. 대만정도관리협회에서는 1998년부터 2005년의 혈 액은행 분과 자료분석에서 $\mathrm{ABO}$ 혈구형과 혈청형 검사를 모 두 시행하는 기관의 비율이 2000년 73.6\%에서 2005년 95.3\% 로 증가하였다고 보고하였다[10]. 이는 2013년 혈구형과 혈청 형을 모두 시행하는 기관의 비율이 약 $94.0 \%$ 나 되는 국내 기 관보다도 높은 비율을 보이고 있으므로, 국내 참여기관들의 정 확한 혈액형검사를 위해서는 신환과 같이 취급하여야 할 외부 신빙도조사용 검체에 대해서는 혈구형 이외에도 혈청형 검사 모두를 시행하도록 홍보가 필요할 것으로 여겨졌다.

2010년까지는 직접항글로불린검사법을 슬라이드법으로 보 고한 기관도 $0.5-1.1 \%$ 나 되어 2011 년부터는 직접항글로불 린검사법 선택 시 교육의 목적으로 슬라이드법은 선택하지 못 하도록 하였다. 그럼에도 불구하고 2011년 이후에도 검사법을 미입력으로 표시한 기관도 드물게 있어서, 이것이 단순한 미입
력인지 혹은 직접항글로불린검사방법을 아직도 슬라이드법으 로 시행하여 선택하지 못한 것인지는 구분할 수 없었으나, 참 여기관에 대한 지속적인 교육이 필요할 것으로 여겨졌다.

국내 기관에서 교차시험과 직접항글로불린검사의 경우 비록 시험관법이 아직도 우세하기는 하나, 이는 점점 감소하고 미 세원응집법을 사용하는 기관이 점점 증가하고 있다. 교차시험 검사법으로 미세원주응집법을 사용하는 기관의 비율이 2013 년의 미국의 $\mathrm{CAP}$ 는 $50 \%$, 2008년 영국 UK NEQAS도 96\% 의 기관으로 보고하여 $16 \%$ 의 국내 기관과는 매우 차이를 보 이고 있는 것으로 나타났다(Table 3). 영국의 경우 교차시험검 사 법의 연도별 변화를 살펴보면 시험관법과 미세원주응집법 의 사용이 1996 년에 $51 \%$ 와 $42 \%$ 였던 것이 2001 년 $15 \%$ 이하 와 $77 \%$ 로 변화하였고, 2005 년 $7 \%$ 이하와 $91 \%$ 로 미세원주응 집법 사용이 급격히 증가하였다[8].

반면 항체선별검사와 항체동정검사의 경우에는 대다수의 국 내 기관에서 미세원주응집법을 사용하고 있으며, 시험관법을 사용하는 기관은 $10 \%$ 미만으로 감소하고 있는 추세를 보이고 있다. 이렇게 높은 미세원주응집법을 이용하는 현상은 2008년 영국 UK NEQAS 보고의 항체선별검사 $90 \%$ 와는 유사하였 으나, 2013년의 CAP자료의 항체선별검사와 항체동정검사에 서 미세원주응집법을 사용하는 기관의 비율이 각각 $65.6 \%$ 와 $61.3 \%$ 에 비하여 오히려 높았다(Table 3). 이는 국내에서 미세 


\section{Journal of LABORATORY MEDICINE and QUALITY ASSURANCE}

Young Ae Lim • Analysis of the Techniques in Blood Bank

원주응집법이 거의 사용되지 않았던 혈액형검사법과는 매우 다른 양상을 보여주었다. 또한 자동화가 가능한 검사법이 국내 에는 미세원주응집법에 한정된 반면, 항체선별검사로 고형상 적혈구부착법이 미국 $3.4 \%$, 영국 $9 \%$ 의 기관이 이용하여 국내 보다 다양한 검사법이 이용되고 있음을 알 수 있었다. 현재 국 내에도 이러한 새로운 기법이 도입되고 있으므로 외부신빙도 조사 검사법 목록에 이들을 추가할 필요가 있겠다.

2008년 영국의 자료에 따르면 참여기관의 $68 \%$ 는 정규업무 시간 중 'type \& screen'을 완전 자동화로 시행한다고 하였는 데, 이는 전체 ‘type \& screen’의 약 88\%에 해당한다고 하였 다[8]. 미국의 보고에서도 미세원주응집법, 고형상적혈구부착 법, 그리고 적혈구자기화법과 같이 자동화가 가능한 새로운 기 법들이 소개된 이후로는 빠르게 의료기관 혈액은행의 자동화 가 진행되고 있다고 언급하였다[4]. 외국의 이러한 자동화 진 행은 낮은 국내 의료보험 수가 때문에 수기화로 대부분의 업무 가 이루어지는 국내의 의료기관의 혈액은행 업무와는 매우 대 조적이라 할 수 있다. 수혈 전 검사업무의 자동화는 인력을 감 소할 수 있으며 대량화가 가능하다는 다른 업무의 자동화와는 달리 수기법으로 인하여 발생할 수 있는 사무적 착오와 기술적 착오를 방지할 수 있으며, 결과의 객관성, 재현성 및 추적성을 가질 수 있다는 큰 장점 때문에〔3] 검사의 착오가 환자의 생명 과도 직결될 수 있는 수혈 전 검사는 반드시 자동화가 필수적 인 업무라고 할 수 있다. 따라서 국내의 대다수의 의료기관에 서도 혈액은행의 수혈 전 검사업무는 자동화가 이루어질 수 있 도록 현실적인 급여체계의 도입이 절실하다고 여겨진다.

\section{REFERENCES}

1. Lim YA, Oh JS, Kwon SW, Kwon KC, Kim SY, Park KU, et al. Annual report on external quality assessment in blood bank tests in Korea (2012). J Lab Med Qual Assu 2012;34(S1):S103-15.
2. Lim YA, Oh JS, Kwon SW, Kwon KC, Kim SY, Park KU, et al. Annual report on external quality assessment in blood bank tests in Korea (2011). J Lab Med Qual Assu 2011;33(S1):S91-104.

3. Bajpai M, Kaur R, Gupta E. Automation in immunohematology. Asian J Transfus Sci 2012;6:140-4.

4. Garratty G. Advances in red blood cell immunology 1960 to 2009. Transfusion 2010;50:526-35.

5. Kwon SW, Kim DW, Han KS, Kim HO, Seo JS, Cha YJ, et al. Annual report on external quality assessment in blood bank tests in Korea (2009). J Lab Med Qual Assu 2010;32:95-101.

6. Kwon SW, Kim DW, Han KS, Kim HO, Seo JS, Cha YJ, et al. Annual report on external quality assessment in blood bank tests in Korea (2008). J Lab Med Qual Assu 2009;31:99-104.

7. Roback JD. Technical manual. 17th. Ed. Bethesda: American Association of Blood Banks, 2011:875-6.

8. UK National External Quality Assessment Scheme. UK National External Quality Assessment Scheme for blood transfusion laboratory practice: bi-ennial report 20072009. Sheffield: UK National External Quality Assessment Scheme, 2009.

9. Shulman IA, Maffei LM, Downes KA. North American pretransfusion testing practices, 2001-2004: results from the College of American Pathologists Interlaboratory Comparison Program survey data, 2001-2004. Arch Pathol Lab Med 2005;129:984-9.

10. Kao CL, Huang YY, Lin WS, Chang LF, Lin DT. Survey of external quality assessment scheme for blood bank laboratories in Taiwan. IJBLS 2011;1:1-14. 


\section{최근 6년간의 국내 검사실의 혈액은행 검사기법 분석}

\section{임영애}

아주대학교 의과대학 진단검사의학교실

배경: 검사의 결과는 사용된 기법에 따라 영향을 받을 수 있는데, 아직 국내 혈액은행검사에 사용되는 기법에 대한 자세한 보고는 없는 실정이다. 이 연구에서는 최근 6년간의 국내 외부신빙도조사를 통하 여 검사실에서 혈액은행검사를 위하여 사용된 기법들의 경향을 조사하고자 하였다.

방법: 대한임상검사정도관리협회의 홈페이지로부터 2008년부터 2013년까지 혈액은행 분과 외부신 빙도조사에 참여하여 응답한 모든 기관들이 검사에 사용된 기법에 관한 자료를 수집하였다. 조사항목 은 $\mathrm{ABO}$ 및 $\mathrm{D}$ 혈액형검사, 교차시험, 직접항글로불린검사, 항체선별검사 및 항체동정검사였다.

결과: 각 검사에 가장 많이 이용된 기법은 다음과 같다 $2008 \& 2013$ 자료, 단 $\mathrm{ABO}$ 혈액형검사 는 $2011 \& 2013$ 자료): $\mathrm{ABO}$ 혈구형 검사 슬라이드법(58.4\% \& 60.8\%), ABO 혈청형 검사 시험 관법(82.0\% \& 85.9\%), D 혈액형검사 슬라이드법(50\% \& 54.6\%), 교차시험 시험관법(91.9\% \& $83.8 \%)$, 직접항글로불린검사 시험관법(63.6\% \& 52.8\%), 항체선별검사 미세원주응집법 $(74.7 \%$ \& 89.4\%), 항체동정검사 미세원주응집법(83.9\% \& 94.2\%).

결론: 최근 6년간 교차시험, 직접항글로불린검사, 항체선별검사 및 항체동정검사에 대해서 시험관법 이 감소하는 대신 미세원주응집법이 꾸준히 증가하는 양상을 보였다. 그러나 혈액형검사에 대해서는 아직도 상당수의 기관에서 슬라이드법을 사용하고 있으므로 검사법의 향상을 위해서는 지속적인 교 육이 필요할 것으로 여겨졌다.

(J Lab Med Qual Assur 2014;36:23-29) 